\title{
PODER REGIO Y MECENAZGO EN EL OCCIDENTE PENINSULAR: LAS REINAS E INFANTAS DE LAS DINASTÍAS TRASTAMARA Y AVÍS ${ }^{1}$
}

\author{
ROYAL POWER AND PATRONAGE IN WESTERN IBERIA: \\ THE QUEENS AND INFANTAS OF THE TRASTAMARA \\ AND AVIS'DINASTIES
}

\author{
ISABEL BECEIRO PITA \\ Instituto de Historia, CCHS, CSIC
}

\begin{abstract}
Resumen: Este trabajo aborda el mecenazgo de las reinas consortes e infantas en el Occidente peninsular, desde una perspectiva de historia comparada. Su finalidad es examinar las líneas de actuación comunes a Castilla y Portugal y, al mismo tiempo, las diferencias entre ambos reinos, en un período comprendido entre los años finales del siglo XIV y los inicios del XVI, correspondiente al gobierno respectivo de los últimos Trastamara y los Avís. El análisis de las manifestaciones de este patrocinio pone de manifiesto una gran variedad temática, dentro del predominio de los contenidos religiosos. Las iniciativas culturales de estas señoras deben ser consideradas en el marco de la exaltación de la monarquía, propia de la génesis del Estado Moderno a fines de la Edad Media y en la época renacentista.
\end{abstract}

Palabras clave: reinas; infantas; poder regio; mecenazgo; instrucción; manuscritos; temas literarios; copias; traducciones; ediciones.

\begin{abstract}
This work deals with the patronage of the queens-consort and princesses in the Western part of the Iberian Peninsula from a comparative point of view. Its main aim is to analyze the ways of acting common both to Castile and Portugal and, at the same time, to examine the differences between both kingdoms in the period that covers the late 14th century and the beginnings of the 16th century, corresponding to the rule of the Trastamara and the Avís dynasties. The analysis of their sponsorship shows a wide variety of themes inside the prevalence of religious subjects. The cultural initiatives of these noble women must be considered in a context where monarchy was highly exalted, a feature characteristic of the origins of the Modern State at the end of the Middle Ages and the Renaissance period.
\end{abstract}

Keywords: queens; princesses; royal power; patronage; literacy; manuscripts; literary matters; translations; prints.

${ }^{1}$ Este artículo se inserta en el proyecto de investigación Identidades, contactos, afinidades: la espiritualidad en la Península Ibérica (siglos XII-XV), financiado por la DIGICYT, con referencia HAR2013-45199-R, y cuya investigadora principal es Isabel Beceiro Pita.

Abreviaturas utilizadas: ANTT $=$ Arquivo Nacional do Torre do Tombo; AHN $=$ Archivo Histórico Nacional; BNL = Biblioteca Nacional de Lisboa; $\mathrm{BNM}=$ Biblioteca Nacional de Madrid; BRME = Biblioteca del Real Monasterio de El Escorial; inc. $=$ incunable; Ms. = manuscrito; RBP = Real Biblioteca de Palacio; Res. = reservado. 


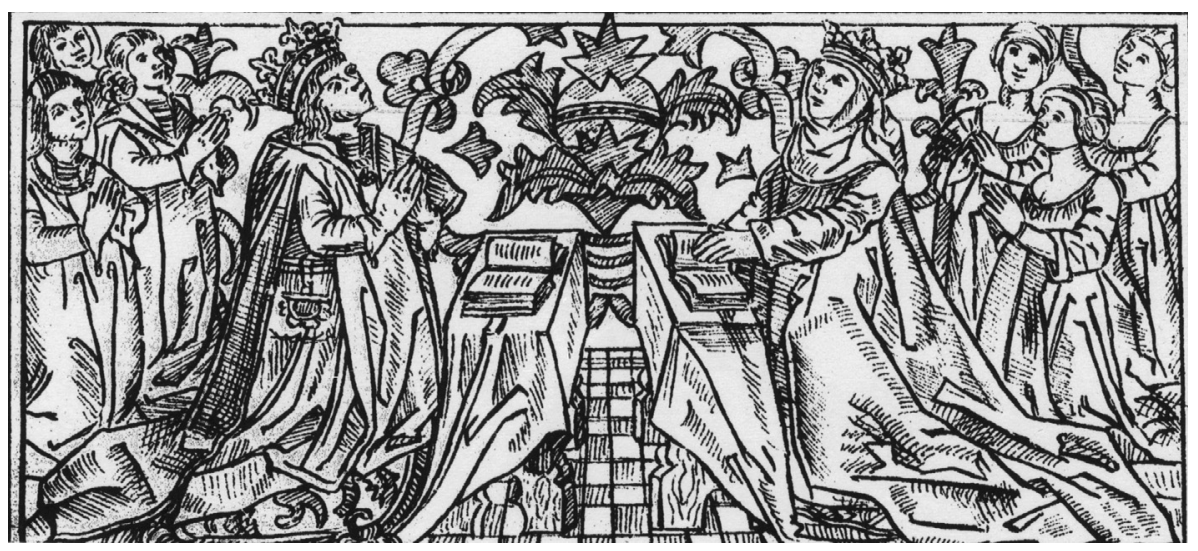

Fig. 1. Don Joâo II de Portugal y su esposa, la reina doña Leonor, en actitud de lectura devota, rodeados por los caballeros y damas de su corte. Viñeta inferior del frontispicio de la primera edición de la Vita Christi en portugués (1495). BNL, Inc. 566.

\section{SUMARIO}

0. Introducción.- 1. Géneros y temas del mecenazgo ejercido por las allegadas al rey.- 1.1. Los tratados piadosos, exegéticos y doctrinales.- 1.1.1. Las obras originales.- 1.1.2. Las copias y traducciones.- 1.1.3. Los incunables.- 1.2. Las obras relacionadas con el buen gobierno.- 1.3. La literatura del mundo clásico.- 1.4. Los tratados ejemplares para mujeres.- 1.5. El teatro y la poesía cortesana.- 2. Conclusiones.3. Bibliografía citada.

\section{INTRODUCCIÓN}

El estudio de la relación entre poder y mecenazgo literario en estos territorios, en el tránsito entre la Edad Media y Moderna, ha centrado su atención, fundamentalmente, en algunas personalidades regias y principescas y en la vinculación de prosistas y poetas en torno a ellos, destacando su bibliofilia, sus afanes culturales o su impulso a la introducción del humanismo. Actualmente, los trabajos sobre las figuras de Juan II e Isabel I en Castilla y de D. Duarte, el infante-regente D. Pedro y D. João II en Portugal, ponen el acento en la relación existente entre estas actividades y la afirmación ideológica de la autoridad regia que tiene lugar durante sus mandatos.

Sus cónyuges ya habían sido objeto de interés dentro de la historia evenemencial, al examinar las distintas coyunturas políticas, sobre todo María de Aragón y Leonor de Avís o Lancáster. En las últimas décadas han recibido 
nuevo impulso desde la óptica de los modelos culturales y, especialmente, del estudio de la condición de la queenship, concepto que ha sido traducido al castellano por el de reginalidad ${ }^{2}$. Las investigaciones de esta reciente línea se han centrado en las capacidades de actuación, las funciones e imagen de la reina consorte. A tenor de los textos cronísticos, lo más valorado en ellas es la colaboración armoniosa con su marido, como en épocas anteriores, y la extrema piedad, virtud en la que se pone gran énfasis a partir de mediados del siglo XIV, en detrimento de la acción política directa ${ }^{3}$. En cambio, los aspectos relativos al mecenazgo han quedado en un segundo plano, aún cuando han sido abordados por Manuela Santos Silva y Diana Pelaz Flores, a propósito de Filipa de Lancáster y María de Aragón, respectivamente ${ }^{4}$.

Por tanto, el objetivo de las páginas siguientes es mostrar que el mecenazgo literario de estas señoras responde a una línea bien definida, sobre todo si se considera en un sentido amplio, que incluye a los letrados y caballeros introducidos en los ámbitos cortesanos por su intervención. En conjunto, su patrocinio sobre tratados, composiciones poéticas y piezas teatrales contribuye a la imagen de la realeza, de forma complementaria a la de sus esposos, padres y hermanos, y presenta modalidades específicas ${ }^{5}$.

En principio, el cotejo de su actividad con la de los varones titulares de la autoridad pone de manifiesto dos ámbitos de actuación, aún cuando no haya una separación absoluta entre ellos. Los libros destinados a los reyes responden a su doble condición de sumo rector de la comunidad y de señor de vasallos guerreros. En consecuencia, consisten esencialmente en tratados históricos y del buen gobierno, libros de caza, arte militar, armas y blasones y, en menor grado, en las composiciones poéticas.

El mecenazgo de las mujeres que ostentan la autoridad, ya sea por derecho propio o de forma delegada y temporal, se inscribe en el primer supuesto, como se puede ver en las obras ofrecidas a Catalina de Lancaster y a Isabel I de Castilla. La regente recibe de Pablo de Santa María Las siete edades del mundo, sin duda por recaer en ella la guarda del entonces menor Juan II $^{6}$.

\footnotetext{
${ }^{2}$ Los trabajos más directamente relacionados con el tema tratado aquí son los de Rodrigues 2007; Pelaz 2013. Núria Silleras es quien más ardientemente ha defendido la traducción castellana de este concepto, Silleras 2005-2006, pp. 121-142.

${ }^{3}$ Jardin 2006.

${ }^{4}$ Silva 2012a; Pelaz 2014.

${ }^{5}$ Sobre el contexto cultural cortesano, véase Gómez Redondo 2007, vol. III.

${ }^{6}$ Esta vinculación entre los tratados históricos y los gobernantes de la corona de Castilla tiene como antecedente más directo la dedicatoria por Lucas de Tuy de su Chronicon mundi a Berenguela y Fernando III. Considero, entonces, que debe entenderse como un motivo secundario, pero no determinante, el patrocinio de las artes y las letras por Catalina, al estilo renacentista, defendido por Echevarría 2005, p. 95.
} 
En el caso de Isabel, varios factores explican, aparte de sus gustos personales, la promoción y apoyo de determinados escritos: la herencia paterna, la defensa de su legitimidad dinástica, el ambiente intelectual y el refinamiento cortesano a partir de la década de 1430, el valor otorgado en toda la baja Edad Media a los libros de educación de príncipes y nobles y la relación de materias como la historiografía, las recopilaciones jurídicas y las ordenanzas legislativas con las tareas dirigentes ${ }^{7}$.

La labor de las soberanas consortes se deriva de su status y papel ideológico. En un sentido amplio, va dirigida al conjunto de los súbitos, de acuerdo con la colaboración que deben prestar a su cónyuge. En un sentido más restringido, tiene como receptor a la población femenina del reino y, en especial, a las señoras y damas de la corte, proponiendo unos modelos de conducta a los que las reinas deben ajustarse, aún más que el resto de las mujeres. Su contenido es de tipo religioso, moral y literario, y guarda puntos de contacto con la educación impartida o supervisada por ellas a los hijos y criados de ambos sexos ${ }^{8}$.

Las empresas intelectuales de las infantas abarcan una gama muy variada, dependiendo de su posición con respecto al poder, su estado y las distintas fases del ciclo vital. Habitualmente, los hombres de letras prestan mucha menos atención a las jóvenes doncellas de la familia del monarca que a los varones, en consonancia con sus menores posibilidades de acceso al trono y es sintomático que únicamente se dedicaran tratados a la princesa Isabel, cuando fue nombrada heredera de Castilla. No obstante, la entrada en un convento ofrece un espacio propicio para dedicarse a la escritura, tal y como lo hicieron las portuguesas Caterina y Filipa. Las casadas centran sus esfuerzos en los territorios de sus esposos, y, en el caso de la duquesa de Borgoña, Isabel de Portugal, contribuyen a la circulación cultural entre el occidente peninsular y su nuevo país.

Dejando de lado a Isabel I de Castilla por ostentar la titularidad del poder, este trabajo centra su atención en los siguientes miembros femeninos de ambas dinastías: Filipa de Lancaster (1360-1415), hija de Juan de Gante, duque de Lancaster, y, mujer de D. João I: Catalina de Lancáster (1372-1418), media-hermana de la anterior, y reina consorte de Castilla por su matrimonio con Enrique III; María de Aragón (1418-1435), hija de Fernando I de Aragón y Leonor de Alburquerque, nieta de los mencionados Catalina y Enrique y primera esposa de Juan II; Leonor de Aragón (1402-1445), hermana de la anterior; mujer de D. Duarte de Portugal, heredero y sucesor de D. Joâo I; Isabel de Urgel (1409-1470), hija del último duque de Urgel, nieta de Pedro el

\footnotetext{
${ }^{7}$ Véase, a este respecto, Salvador 2004a, 2004b, 2009.

${ }^{8}$ Beceiro 2007a, pp. 310-319.
} 
Ceremonioso de Aragón, casada con el infante-regente de Portugal D. Pedro, hermano de D. Duarte; Isabel de Portugal (1428-1496), hermana de D. Duarte, D. Pedro y D. Juan, y duquesa de Borgoña, por su enlace con Felipe el Bueno; Isabel de Coímbra (1432-1455), hija del mencionado infante-regente, casada con su primo y sucesor de D. Duarte, Afonso V el Africano; Isabel de Portugal (1428-1496), hija del infante D. Fernando, duque de Aveiro, nieta de D. Joâo I de Portugal, segunda mujer de Juan II de Castilla y madre de Isabel I; las infantas reclusas Catalina y Felipa de Portugal (1436-1463) y (1435-1497), hijas respectivas de D. Duarte y del infante-regente; y, finalmente, Leonor de Lancaster o Viseu, hija de don Fernando, duque de Viseu, nieta de don Duarte, casada con don João II, princesa de Portugal a partir de 1471, soberana consorte entre 1481 y 1495 y reina viuda hasta 1525 .

En este conjunto destacan María de Aragón y Leonor de de Lancáster, seguidas de la duquesa de Borgoña e Isabel de Coímbra. Las iniciativas de todas ellas enmarcan en un período de florecimiento de la cultura cortesana en ambos reinos, que es inseparable de la afirmación de la autoridad regia.

\section{GÉNEROS Y TEMAS DEL MECENAZGO EJERCIDO POR LAS ALLEGADAS AL REY}

Para una mejor comprensión de la actividad de la parentela regia femenina en este aspecto, se ha optado aquí por establecer una división temática, en lugar de tomar como base las respectivas formaciones políticas y atender a cada una de las señoras vinculadas a la monarquía. Hay que advertir, sin embargo, de lo artificial de esta división para el medievo, ya que en este período no existe, como en la actualidad, una separación entre las distintas materias. Como se verá en las páginas siguientes, muchas veces es imposible deslindar el contenido religioso, moral o literario de una obra de su vertiente política, en una dualidad significativa que se observa también en la recepción de los escritos procedentes del legado clásico. Los mismos problemas plantea el campo literario, ya que la mayoría de los escritos elaborados en Edad Media y los inicios del siglo XVI posee un carácter didáctico y ejemplar, que impregna la ficción poética, novelesca o teatral.

\subsection{Los tratados piadosos, exegéticos y doctrinales}

Comprenden la mayor parte de las iniciativas, que no sólo se traducen en la encomienda de copias, traducciones y ediciones impresas, sino también en la solicitud de textos específicos. 


\subsubsection{Las obras originales}

En este aspecto, hay que destacar la actividad de María de Aragón, primera esposa de Juan II. Guarda unas pautas similares a las del rey, lo que pone de relieve la complejidad de este personaje. Se posiciona abiertamente a favor de sus hermanos y en contra de don Álvaro de Luna y su marido, lo que le aleja de la imagen ejemplar propuesta a las reinas bajomedievales ${ }^{9}$. Sin embargo, en materia cultural practica esa cooperación requerida a las consortes.

Hacia 1435 doña María pide a Alonso Fernández de Madrigal, el Tostado, que le aclare ciertas ocultas metáphoras, correspondientes a cinco propiedades de la simbología mariana y cristológica. Las primeras explican la consideración de la Virgen como vaso çerrado et non çerrado; pequeño et non pequeño, lumbroso et non lumbroso; vazío et non vazío, más vaso limpio et non limpio, mientras que las cristológicas desarrollan la interpretación de la figura de Jesús como león, cordero, serpiente y águila ${ }^{10}$. La consecuencia es un extenso tratado de carácter doctrinal y teológico, acabado en 1437, y que lleva por título Libro de las çinco figuratas paradoxas. Está estructurado en apartados referentes a estas expresiones, el inicial para las marianas y el resto para las relativas a Cristo. En los respectivos párrafos introductorios, expone el autor reiteradamente que cumple el mandato de doña María y responde a las cuestiones planteadas en la cédula enviada por ella. El colofón y dedicatoria final anima a la reina a la lectura de la obra y a no despreciar el conocimiento y comprensión de estas figuras, porque aun cuando non son assentadas en el canon de la sancta Scriptura, están fundamentadas en las maneras de fablar de todos los sanctos doctore ${ }^{11}$. En el mismo año de 1437, el Tostado realiza una nueva versión de esta obra en latín, dedicándosela entonces a Juan $\mathrm{II}^{12}$, que pasó después a la biblioteca de su hija, la reina Isabel ${ }^{13}$. A primera vista, podría pensarse que el empleo sucesivo de las dos lenguas indicaría un deficiente o nulo conocimiento del idioma culto por la soberana consorte y, en cambio, el dominio de éste por su marido. Sin embargo, estimo que el motivo fundamen-

\footnotetext{
${ }^{9}$ Puede verse una visión panorámica de su intervención en la esfera política en Álvarez 2006. Véase también Echevarría 2012.

${ }^{10}$ Parrilla 2004-2005, pp. 367-390.

${ }^{11}$ Parrilla 1998, pp. 69, 213, 345, 427, 547, 819-820.

${ }^{12}$ Cátedra 1989, p. 24.

${ }^{13}$ Figura en un asiento del inventario de bienes del alcázar de Segovia: "Otro libro de quarto de pliego entero, de pergamino, en latín, de mano, que son Metáforas, tiene en la primera plana una viñeta con las armas reales de Castilla y León. Tiene las tablas de cuero colorado y en ellas dos charnelas quebradas de plata dorada, cada una con tres clavijas de plata", Ruiz 2004, [98], pp. 297, 478. El hecho de que esté escrito en latín habla bien a las claras de que se trata del ejemplar ofrecido al monarca, y no el de la reina, como supone esta investigadora.
} 
tal es que cada tratado está concebido para un tipo diferente de receptores. El elaborado en romance estaría destinado a la mayoría de la corte, incluyendo a las damas, mientras que el segundo tiene en cuenta a los eclesiásticos que han de ejercer un menester pastoral y exegético, y a los titulados universitarios que participan en los organismos del naciente Estado. Esta hipótesis se encuentra corroborada por las diferencias existentes entre ambos textos. En el latino, determinadas materias están más extensamente tratadas. Algunas corresponden a asuntos que pueden juzgarse indecorosos para oídos femeninos, como la explicación sobre los genitales masculinos y su función procreadora. Pero, en su mayor parte, incluyen una mayor carga erudita y especializada, siguiendo muy de cerca las pautas de la repetitio, utilizadas por Alfonso Fernández de Madrigal y los otros miembros del claustro salmantino. Y, de manera general, se recurre en esta versión a un número más cuantioso de autoridades, sustituyendo, además, la expresión directa de algunos contenidos en la castellana, por glosas o tecnicismos ${ }^{14}$.

Según el padre Flórez, El Tostado escribe igualmente, a instancias de la reina, el Tratado del modo de confesarse y casos de conciencia ${ }^{15}$. Antonio García y García cita entre las obras de este autor un Confessional, la Breve forma de confesión y la Suma de casos de conciencia, que reconoce no haber podido localizar ${ }^{16}$. Quizás serían variantes del Tratado de confision o de la Suma de confession, que se conservan en la biblioteca del monasterio de El Escorial, y podrían constituir adaptaciones de la segunda de estas obras. El Tratado comprende las infracciones a la ley de Dios relativas a cada uno de los pecados capitales, los casos reservados a la autoridad papal, los mandamientos y tres adicciones. La primera, escrita en la misma época, reproduce los Castigos y dotrinas que vn sabio daua a sus hijas, y otras dos posteriores, relativas a textos de san Juan Crisóstomo ${ }^{17}$. La Suma, que se corresponde con un asiento de la biblioteca de Isabel $\mathrm{I}^{18}$, coincide con el manuscrito anterior en los tres primeros apartados, incluye los mandamientos y carece, en cambio, de los citados añadidos ${ }^{19}$.

\footnotetext{
${ }^{14}$ Parrilla 2004, pp. 125-143.

${ }^{15}$ Flórez 2002, vol. II, p. 728.

${ }^{16}$ García 1976, pp. 352-354

${ }^{17}$ BRME, Ms. a.IV.5. Tiene como título inicial "Tratado de confision hecho por el tostado [sic] alfonso de madrigal obispo de Auila". En cuanto a los "Castigos y dotrinas" han sido editados y comentados, entre otros, por Cano 1989.

18 "Otro libro en rromanze, escrito de mano, en papel, enquadernado en tablas, de a quarto grande, que se yntitula Suma de confesión, por el maestro Alonso de Madrigal", Ruiz 2004, pp. 506-507, doc. 25, "Relación de los libros procedentes de la Capilla Real de la catedral de Granada que fueron enviados a El Escorial por orden de Felipe II", D2, 27, p. 356.

${ }^{19}$ BRME, Ms. a.IV.4. El título, en tinta roja, es el siguiente: "Aqui comiença vna suma de confession que conpuso maestre alfonso de madrigal maestre escuela de salamanca". Al igual que el manuscrito ya mencionado, no contiene ninguna dedicatoria ni indicación de un posible
} 
No existen, o no se han conservado, tratados portugueses de este tipo, compuestos a instancias de las reinas e infantas. Allí, la autoría corre a cargo de dos damas de la parentela regia que optaron por la vida conventual: Caterina, hija del monarca don Duarte, y Filipa, aunque esta última no sea fruto de un matrimonio regio, sino del contraído entre el infante-regente don Pedro e Isabel de Urgel. Evidentemente, su actividad no puede calificarse de mecenazgo. Sin embargo, se ha traído a colación aquí porque se inserta en la imagen de la exaltación de la realeza con la dinastía Avís, uno de cuyos principales elementos es la santidad del soberano y de sus familiares En efecto, ambas personifican el modelo de vida bienaventurada, basada en la castidad monástica, que también representa, años después, doña Johana, hija de Alfonso $\mathrm{V}$ el Africano ${ }^{20}$.

La infanta Caterina tuvo una educación esmerada, pues en 1454 el regente don Pedro le asignó como maestro a Jorge Costa, canónigo de la catedral de Lisboa, deán de Lisboa en 1463, arzobispo de esta sede en 1464 y, en tiempos de D. João II, cardenal de Alpedrinha ${ }^{21}$. En 1453 se adquirió para ella y para doña Johana, que luego casaría con Enrique IV de Castilla, dos liuros de gramática darte noua (...) E un briuario de rezar ${ }^{22}$. Se había concertado para ella un matrimonio con el príncipe de Viana, pero, tras el fallecimiento de éste, fue llevada al monasterio de Santa Clara de Lisboa, donde falleció con nome de muy honesta e virtuosa Pryncesa ${ }^{23}$. Se le atribuyen varias obras religioso-morales.

Doña Filipa había sido acogida por su hermana, la reina Isabel, cuando se produjo la guerra civil que terminó con la derrota y muerte del infante-regente. Durante sus últimos diecisiete años viveo e acabou muy honesta e santamente no mosteiro d'Odivellas, aunque sin profesar en la orden ${ }^{24}$. Allí educó a su sobrina Johana, antes de que ésta ingresara en el convento de San Jesús de Aveiro $^{25}$. Se la supone autora de varios poemas y traducciones, entre ellas los Evangelios e homilías de todo o ano, y, además, de un libro de Meditaciones y un Tratado de vida solitaria ${ }^{26}$.

comendatario. Todo parece indicar que tanto uno como otro son copias realizadas poco después de la confección del original, en un período de tiempo no superior a las dos décadas.

${ }^{20}$ Beceiro 1998, pp. 25-26.

${ }^{21}$ Tejada 1998, p. 168.

${ }^{22}$ Évora, 26 de abril de 1453, "Quitación al tesorero de las infantas doña Caterina y doña Johana", ANTT. Livro 1 de Extras, ff. $62 \mathrm{v}-65 \mathrm{v}$. La referencia a la reina Isabel alude a la esposa de Afonso V de Portugal.

${ }^{23}$ Almeida 1977a, p. 794.

${ }^{24}$ Ibidem, p. 755.

${ }^{25}$ Ibidem, p. 826.

${ }^{26}$ Reinhardt, Santiago-Otero 1986, p. 136; Martins 1972. 


\subsubsection{Las copias y traducciones}

María de Aragón ordenó realizar un ejemplar castellano de la exposición del De civitate Dei, de san Agustín, que fue terminado el 27 de abril de 1434, y se encontraba, en 1503, en la biblioteca de Isabel I de Castilla ${ }^{27}$. Debe identificarse con los manuscritos de El Escorial a.1.8 y a. 1.9. El primero de ellos, que correspondiente a la segunda parte del tratado, certifica el encargo de la reina y da noticias del copista, su criado Gómez García de Castilla, distinto del trasladador, que adjunta sus explicaciones a cada capítulo ${ }^{28}$ :

Este libro q[ue] se llama la segunda p[ar]te de la çibdat de dios El qual fiso e ordeno el muy glorioso dotor señor sant agustin escriuio p[ar]a la muy esclaresçida reyna doña maría fija del muy esclaresçido rey don ferran[n]do de Aragon q[ue] aya santa gloria e muger q[ue] agora es del muy excelent[e] señor don iohan rey de castilla e de leon. gomes g[arc]i[a] del castillo criado de la dicha señora reyna por su ruego e mandado acabolo de escriuir enla villa de Vall[adol]id de XXVII dias del mes de abril del año de IUCCCCXXXIIII años Amada e honrrada sea la santa trinitat amen. Gomes Garçia ${ }^{29}$.

En 1442 solicitó a fray Gonzalo de Ocaña, prior del monasterio jerónimo de Santa María de Sisla, una traducción de las Homilías de San Gregorio sobre Ezequiel. El prólogo del fraile jerónimo une el elogio al interés de la reina por las letras sagradas con una exaltación de la importancia de la justicia, como virtud que los soberanos deben poseer y estimar por encima de cualquier otra, para concluir con una breve referencia a las Homilías de San Gregorio, que sólo comentan parcialmente el texto del profeta debido a la intranquilidad en que se hallaba por entonces la ciudad de Roma ante la presencia de los lombardos ${ }^{30}$.

No se sabe si Filipa de Lancáster, mujer de don João I entre 1387 y 1415, intervino en la traducción al portugués de la Confessio amantis de John Gower. Ésta fue llevada a cabo por el inglés Robert Paym, canónigo de la catedral lisboeta, oficial de la soberana entre 1402 y 1405, y familiar de uno

\footnotetext{
${ }^{27}$ Ruiz 2004, p. 372.

${ }^{28}$ Lamento disentir en este punto, del artículo, en otros aspectos tan útil y tan bien documentado, de Alvar, Lucía 2003, p. 15. Aparte de la mencionada diferencia con el "trasladador", el término escribir hace referencia habitualmente, en este contexto, a copiar mientras que para el quehacer del traductor-adaptador se reserva aquí, como ya se ha apuntado, el de trasladar y, en general, las expresiones concernientes a verter o tornar un texto de una lengua a otra.

${ }^{29}$ RBME, Ms. a.I.8, f. 222 b.

${ }^{30}$ Alvar, Lucía 2003, pp. 31-32.
} 
de sus escribanos de la poridad ${ }^{31}$, La calidad y precisión terminológica lleva a preguntarse, con Antonio Cortijo Ocaña, si adquirió el inglés tal manejo y soltura en la lengua de su país de adopción o trabajó en la traducción juntamente con algún clérigo luso ${ }^{32}$.

Los problemas en torno a la fecha de la labor de Paym y los motivos que le llevaron a emprenderla han dado lugar a hipótesis muy diversas, que abarcan desde el encargo regio, la elaboración posterior al fallecimiento de la soberana, o, incluso, la posibilidad de que la obra fuera traída a la Península por Catalina, hermana de ésta y casada con Enrique III de Castilla ${ }^{33}$. Las últimas investigaciones se inclinan por datar esta versión en época posterior al fallecimiento de la reina, y que pudo ser realizada a instancias de don Duarte, monarca bien conocido por sus afanes culturales y sus iniciativas traductoras ${ }^{34}$.

De cualquier forma, la Confessio amantis formaba parte de la biblioteca de este soberano ${ }^{35}$ que, además, hace referencia en el Leal conselheiro a las historias incluidas allí por su autor de que se filham grandes bons conselhos e avisamentos ${ }^{36}$. Esta expresión nos indica que el aprecio regio estaba motivado por su sentido didáctico, y por la unión del tratamiento de los vicios $\mathrm{y}$ virtudes y de los pecados capitales con el retrato del rey sabio, justo y virtuoso, dentro de la tradición de los tratados de espejos de príncipes $^{37}$.

Por otra parte, su presencia en la livraría real remite a la intensificación de los contactos culturales con Inglaterra, debido a la nacionalidad de la reina y, más en concreto, a la estrecha relación de John Gower con la casa de Lancáster.La primera versión de este tratado, de 1390, fue ofrecida a Ricardo II. Sin embargo, durante este mismo reinado, el escritor dedicó tres años después una segunda versión al futuro Enrique IV, hermano de doña Filipa. Después de la crisis política que culminó en 1399, con la deposición de Ricardo II y la ascensión de Enrique IV al trono, Gower asumió el estatuto de destacado apologista de la nueva dinastía. En este contexto, no es de extrañar que la obra de John Gower gozara de gran acogida en los círculos aristocráticos, que los hijos del rey poseyeran ejemplares del mencionado libro y que se efectuaran numerosas copias de él, algunas iluminadas, entre fines del siglo XIV y a lo

\footnotetext{
${ }^{31}$ Silva 2012b, pp. 170-172. Véase el trabajo de Olivera Serrano en este volumen.

${ }^{32}$ Cortijo 1995.

${ }_{33}^{33}$ Para la acogida de esta obra se han seguido los planteamientos de Buescu 2001, pp. 67-75.

${ }^{34}$ Santano 1989.

${ }^{35}$ Hay que entender así la mención de "o amante", dentro de los "liuros de lingoajem do claro rey dom duarte", Duarte 1982b, p. 207.

${ }^{36}$ Ibidem, p. 28.

${ }^{37}$ Cortijo 2007; Cortijo, Oliveira 2007.
} 
largo del XV. Por tanto, puede considerarse la llegada de este manuscrito a Portugal como un vínculo con el legado familiar de la reina y es lógico pensar que fue doña Filipa quien lo dio a conocer a su hijo, aunque no haya pruebas documentales sobre ello.

La versión lusa es conocida actualmente gracias a una copia realizada en Ceuta, en 1430, por mandato de Fernando de Castro o Moço que se conserva en la Real Biblioteca de Madrid ${ }^{38}$. A partir de ella fue vertida al castellano entre 1438 y 1454 por Juan de Cuenca, en donde se da noticias del trabajo de Paym:

Este libro es llamado confisyon del amante, el qual compuso Juan Goer, natural del rreyno de Ynglaterra, et fue tornado en lenguaje portugués por Roberto Paym natural del dicho rreyno et canónigo de la çibdad de Lisboa. Et después fue sacado en lenguaje castellano por Juan de Cuenca, vezino de la çibdad de Huete ${ }^{39}$.

Existe, además, otro volumen conservado en los fondos del monasterio de El Escorial, escrito, probablemente, a finales de la centuria.

La recepción de la Confessio Amantis en Castilla y Portugal pone de manifiesto el papel desempeñado por el círculo de las reinas e infantas casadas con un príncipe o señor extranjero en la circulación de manuscritos entre su país de origen y el de destino que, en el caso ibérico, se extiende a las dos formaciones políticas del occidente peninsular ${ }^{40}$.

La misma labor será efectuada por la duquesa Isabel de Borgoña, hija de la soberana anterior. Muy probablemente, favoreció la introducción en Portugal de la Vita Christi. Tradicionalmente se había dado crédito a los colofones insertos en cuatro volúmenes de la primera edición incunable, que hacían recaer la responsabilidad de la traducción en Isabel de Urgel, esposa del infante don Pedro y duquesa de Coímbra, quien habría encargado su realización a fray Bernardo de Alcobaça. Pero en los últimos años, Aires A. Nascimento ha demostrado la falsedad de este dato, avanzando varias hipótesis para explicar el complicado proceso seguido por la traducción al portugués, en el que participan, además del rey don Duarte, varias reinas, infantas y señoras de la dinastía Avís ${ }^{41}$. En este sentido, puede ser considerado una empresa fa-

\footnotetext{
${ }^{38}$ RBP, II/3088. En el folio CCLVIv se dice: "Este lyvro per graça do muy alto senhor deus screuto per mandado de Dom Fernando de Castro, o moço na cidade de Cepta em XXXta. dias no ano de 1430. Joham Barroso". Para más indicaciones sobre este manuscrito, véase Cortijo 1995, pp. 457-466.

${ }^{39}$ BRME, g.II.19. La fecha aproximada de 1487 ha sido establecida por Bernardo Santano Moreno a partir de la letra y filigranas de este ejemplar.

${ }^{40}$ Cortijo 2000.

${ }^{41}$ Nascimento 2001, pp. 125-142.
} 
miliar, que recaería fundamentalmente en sus más destacados componentes femeninos, a lo largo de tres generaciones. En síntesis, sus principales pasos serían los siguientes:

a) El texto latino sería conocido por el citado monarca antes de 1433, ya que incluye una extensa paráfrasis de la obra en su propio tratado $O$ Leal conselheiro. Pudo haber sido enviado por su hermana, la duquesa de Borgoña, dada su estrecha relación con la Cartuja, orden a la que pertenecía Ludolfo de Sajonia, y que, en opinión de la mayoría de los estudiosos que han abordado el tema, habría servido de intermediaria para que llegara a manos del soberano un libro de Horas iluminado, y confeccionado, precisamente, en Flandes.

b) Entre esa fecha y 1438, fecha del fallecimiento de D. Duarte, es vertido, total o parcialmente, a la lengua vernácula. Con posterioridad, pasa el ejemplar al monasterio de Alcobaça, a través de fray Estevão de Aguiar, personalidad vinculada a la Corona y abad del monasterio a partir de 1431. Hacia 1445-1446 sería reproducido y completado con anotaciones y un prólogo.

c) En 1444, Isabel de Urgel, duquesa de Coímbra, ordena realizar una copia del original en latín a su mozo de cámara o escribano de la poridad, João de Colonia y, al menos dos años después, adquiriría del centro abacial un manuscrito que tendría incorporadas las aludidas correcciones.

d) Esta última versión habría pasado a la hija de esta duquesa, casada con don Afonso V, y llegado al conocimiento de su pariente y sucesora en el trono doña Leonor, que la tomó como base para nuevas reproducciones, efectuadas entre 1490 y 1494, y mandadas enmendar a fray André y otros frailes franciscanos. El resultado final sería la edición de 1495 .

\subsubsection{Los incunables.}

Las primeras obras impresas en ese país, de carácter religioso, fueron promovidas y, a veces financiadas, por doña Leonor, mujer de don João $\mathrm{II}^{42}$. Tal iniciativa enlaza con la personalidad de la reina, su semblanza encomiástica, y la coyuntura política, intelectual y económica lusa.

\footnotetext{
${ }^{42}$ Para una visión de conjunto de este personaje, véase Sá 2011.
} 
Su devoción y obras caritativas le valieron fama de santidad ${ }^{43}$, aproximándola, en algunos aspectos, al modelo representado por Isabel de Hungría y su descendiente Isabel de Aragón o Portugal. Se traduce en empresas piadosas que conjugan la colaboración con su marido con sus propios empeños, puestos de manifiesto en la refundación del hospital de Caldas da Rainha ${ }^{44}$. Al mismo tiempo, se trata de una personalidad activa, que gobernó el reino, siendo princesa, cuando el heredero marchó a Castilla en ayuda de su padre, durante la guerra de Sucesión ${ }^{45}$.

Sus gustos culturales no se reducían a los escritos de liturgia, rezo y fervor. Entre los libros entregados tras su fallecimiento a las clarisas de Madre de Deus de Xábregas figuraban, además, de Breviarios, diurnaes, cadernos, contemplaçôes, oraçôes ${ }^{46}$ y tratados exegéticos y morales, la Coroaçam de Joham de Mena, el De propietatibus rerum, la Crónica de Boemia, Marco Paulo, De agricultura, el Compendio da saúde humana y la Estoria de Melusina ${ }^{47}$. En conjunto, denotan la inserción de la soberana en la cultura aristocrática del occidente peninsular y la afición por los temas artúricos y novelescos, que era mucho más acusada en la corte lisboeta que en la castellana.

Hay que recordar que su dilatada vida pública tiene lugar, básicamente, durante el mandato de su esposo, el denominado Príncipe Perfeito y luego de su hermano, Manuel I el Afortunado, que marcan el apogeo de los Avís y el comienzo de los Bragança, la prosperidad económica del reino en relación con las empresas africanas, la irrupción de las ideas humanistas y la retórica del poder, propia del renacimiento, que une la mencionada imagen de la religiosidad con el patronato sobre las armas y las letras. En este contexto, no es de extrañar la progresiva intensificación de los elementos laudatorios en los retratos cronísticos de doña Leonor. Así, mientras que el trazado por Ruy de Pina recalca su sangre real y recurre al tópico de la perfección, ya utilizado para soberanas anteriores - por seu Real sangue, muytas bondades, e gram perfeiçam era dina de hum grande Emperador ${ }^{48}$-, la semblanza de García de Resende se explaya en una loa más en sintonía con el estilo renacentista:

${ }^{43}$ El cronista Ruy de Pina decía de ella que era "em todo muito amiga de Deos e d'ElRey", Almeida 1977b, p. 1020.

${ }^{44}$ Coelho 2005, pp. 174-175.

45 "E por consentimento del Rey seu pay deixou o regimento, e gouernança do Reyno ã Princesa dona Lianor sua molher, e com ella deixou pessoas de muyta auctoridade, e letras, e bom conselho, com que nas cousas do Reyno se aconselhasse", Serrão 1973, p. 10.

${ }^{46}$ Martins 1972, vol. I, pp. 189-190.

${ }^{47}$ Villares 1987, pp. 51-81.

${ }^{48}$ Almeida 1977a, p. 615. 
A qual Princesa era tão singular pessoa, e de tão grandes virtudes, e bondades, e de tanta fermosura, manhas, e gentileza, tam acabada, e perfeita, que parece, que como ambos naceram tão excelentes, logo nosso Senhor ordenou, que elle não podesse achar outra tal molher, nem ella tan magnanimo marido ${ }^{49}$.

Dentro de su labor de mecenazgo, intervino muy significativamente en la publicación de los primeros incunables de la Vita Christi, el Bosco deleitoso y los Autos dos Apóstolos, dejando aparte otro de temática diferente, que será tratado al hablar del patrocinio literario ${ }^{50}$.

La edición de la obra de El Cartujano es la más temprana, pues data de 1495. Es la única llevada a cabo antes del fallecimiento de don João $0^{51}$, y, posteriormente, debió de pasar a formar parte de la biblioteca de don Manuel I el Afortunado, su sucesor en el trono ${ }^{52}$. Se inicia con un proemio de los editores Valentín de Moravia y Nicolás de Sajonia, que, al igual que otros libreros del Occidente europeo, adoptan la postura del donante, antes reservada al autor ${ }^{53}$. Quizás busquen con ello reclamar para la imprenta una protección semejante a la que ya disfrutaba en Castilla. En cualquier caso, este prefacio no deja de resultar sorprendente en relación con otros escritos por miembros del mismo oficio, ya que desarrolla argumentos basados en las teorías políticas de la realeza ${ }^{54}$. Valentín y Nicolás ofrecen el trabajo surgido de sus prensas a la pareja regia, pero sitúan al monarca en un plano superior, como máximo poder del reino. La reina, por su posición inmediatamente inferior aparece implícitamente en el papel de colaboradora de su cónyuge y, a la vez, en el de intermediaria, que recuerda al de la Virgen María con respecto a Jesucristo, y, en definitiva, muchas de sus diligencias pueden ser entendidas como instancias necesarias para que determinadas empresas tengan éxito.

Este reparto de funciones queda patente en la explicación de las causas que hacen conveniente la acogida del libro por el titular de la Corona. Parten del concepto de la sabiduría como atributo de la divinidad y el buen

\footnotetext{
${ }^{49}$ Serrâo 1973, p. 4.

${ }^{50}$ Martins 1958, pp. 249-257.

${ }^{51}$ Vita Christi de Ludolfo de Sajonia, BNL, 1a y 2a parte, incs. 566 y 567.

52 "It.Huû livro de Vita XPy de primeira e segunda parte, de papel, esprito de letra de forma, ĕcadenado de tavoas cuberta de couro vermelho em ouro, con huûs pregos de latã", Viterbo 1901, [39], p. 16.

${ }^{53}$ Chartier 1996, pp. 202-203.

54 "Prohemial epístola ao sereníssimo príncipe el Rey potentíssimo e senhor dom Joham osegundo Rey de Portugal e doa algarues daque[m] e dalem mar en affrica senhor de guynee dirigida. preposta em lectura da vida de $\mathrm{Xr}[$ ist $]$ o. per ordena[n]ça e mandado da muy esclareçida de sangue e virtudes e antre as prinçesas da cristandade yllustríssima senhoa raynha dona Lyanor sua muy virtuosa molher inpressa pellos honrrados meestres e empressores feliçemente se começa", Vita Christi de Ludolfo de Sajonia, BNL, inc. 566, ff. 2r-3v.
} 
gobernante cristiano y, en consecuencia, la necesidad de que éste último conozca la vida de Cristo y procure la salvación de sus almas difundiéndola entre su pueblo, especialmente en un momento en el que la reciente expansión ultramarina comporta la perentoria tarea de evangelizar a los nuevos súbditos. El significado otorgado a esta obra como instrumento de la monarquía lleva a pensar que razones similares pudieron haber determinado la dedicatoria a Isabel I de Castilla de la edición de Alcalá de Henares, en 1502.

Doña Leonor participa de las directrices rectoras de su esposo en su preocupación por el bien común del reino y por la salud material y espiritual de sus habitantes, que habrá de redundar en el galardón de la vida eterna:

E semdo ha sereníssima Senhora Raynha de seu proprio natural muy virtuosa e a todo acrescentame[n]to e be[m] da re pubrica destos regnos e senhoríos: segu[n]do seu poder e boa vontade naturalme[n]te inclinada. ...]no[n] soome[n]te nas cousas $q[u e]$ a corporal visa co[n]uem: mas per hu[n]a singular e virtuosa inclinaçam aq[ue]llas que ao spiritual viuer pertençe: e consirando sua alteya qua[m] grande he ho premio da quelles que os outros asaluaçam das suas almas per vertuosos meos prouoca[m].

La decisión de publicar este libro constituye, en este proemio, la mejor muestra de sus cualidades y línea de conducta con respecto a la comunidad, que la asocian al Príncipe, más allá del vínculo matrimonial:

e visto como nestes regnos som muyto mais os vulgares que os que alingua latina conhecem: (...) mandou esta[m]par e de forma fazer en lingoa materna e portugues linguagem: como de feito com diuino fauor per obra comprio: com muyta dispeza de sua fazenda: por seruiço de nosso senhos e porueito comuu[n]: as quatro partes do liuro intitulado vita $\mathrm{Xr}$ [ist]i (...) ordenado e composto pello reuere[n]do padre Ludolfo Cartusiano: chamado meditações da vida de Ihessu: no qual se co[n]tem todollos mysterios da ffe catholica ${ }^{55}$.

Los otros libros que patrocina son ya de los dos primeros decenios del siglo XVI e incluyen dedicatorias mucho menos extensas y laudatorias, muy probablemente porque su edición carece del carácter de empresa regia, al haber fallecido don João. De estos dos, hubo una mayor influencia de la reina viuda en los Autos dos Apóstolos, de 1505, ya que no sólo ordenó la publicación, sino que encargó a Valentim Fernándes -antes llamado Valentín de Moravia- que escribiera un prólogo, del que carecía el original manuscrito. En él abunda el impresor en la idea de que las iniciativas de de doña Leonor

${ }^{55}$ Ambas citas están extraídas del BNL, inc. 566, f. 3. 
tienen la finalidad de proveer al sustento espiritual de su pueblo, y, en cuanto a la obra, declara que el autor es Bernardo de Brihuega, colaborador de Alfonso X, que participó en la General Estoria, y contiene su segundo libro recopilatorio, concerniente a la vida y pasiones de los Apóstoles ${ }^{56}$.

No se conoce ninguna versión castellana de este tratado, pero el manuscrito luso se hallaba en la biblioteca de don Alfonso Tenorio, adelantado de Cazorla, fallecido en 1430, y descendiente directo de nobles exiliados en el reino tras la batalla de Aljubarrota, pues era sobrino del célebre arzobispo de Tenorio e hijo de su hermana Urraca y Aires Gómes de Silva, ayo de don Fernando I. Hay que suponer, por tanto, que los Silva-Tenorio llevaron consigo el ejemplar de los Autos, al abandonar su país, hipótesis que se ve reforzada por la existencia entre los bienes del adelantado de otro libro en portugués ${ }^{57}$. La edición de 1505 tendría como base entonces un texto similar a éste, copiado sucesivamente, y quizá, corregido, por fray Bernardo y fray Nicolau Vieira, monjes de Alcobaça, por mandato del abad fray Estevão de Aguiar, dando fin a su tarea en 1443, y que, muy probablemente, se correspondería con el ejemplar que la esposa de Afonso V incluyó en 1452 entre sus mandas testamentarias ${ }^{58}$.

Más escuetas son las referencias a doña Leonor en el prólogo de Hermán Campos a la primera impresión del Bosco deleitoso, en $1515^{59}$. El editor se dirige a esta señora con la fórmula tópica de muyto esclarecida e devotísima Raynha y expone que los motivos que llevaron a ésta a ordenar que fuera publicada por la imprenta son el ya reiterado celo por su salvación y el de todos los cristianos y, por otra parte, el gusto por la dulzura espiritual de este tratado. De hecho, el Bosco, incluido en el legado regio al convento de Madre de Deus $^{60}$, se adscribe al género de la espiritualidad afectiva desde la experiencia del amor místico ${ }^{61}$. Constituye una paráfrasis parcial del De vita solitaria de Petrarca, con la adicción de 46 capítulos, que se supone escrita por un clérigo de Alcobaça entre fines del siglo XIV y comienzos del XV.

${ }^{56}$ Martins 1965,pp. 69-86,

${ }^{57} \mathrm{El}$ asiento 14 de este inventario dice: "Otro libro escripto en papel toledano en lenguaje portogués que dis que es el segundo libro que fabla de los fechos delas posesiones de los apóstoles con coberturas de madera con cuero blanco". La indicación del tema y no del título podría indicar que éste era desconocido para el copista. Por lo demás, la biblioteca de don Alfonso Tenorio es la única perteneciente a nobles castellanos que incluye volúmenes escritos en el idioma luso, Beceiro, Franco 2007, pp. 348-360, 395-399.

585 de febrero de 1452. Cédulas testamentarias de doña Isabel, mujer de don Afonso V el Africano, insertas por éste en una carta suya, del 25 de mayo de 1456, Monumenta Henricina 1974, núm. 188, p. 434.

${ }^{59} \mathrm{El}$ incunable se conserva en la BNL, Res. 176, pero falta la primera hoja, que es la que correspondería, justamente, a la dedicatoria.

${ }^{60}$ Villares 1987, [31], p. 66.

${ }^{61}$ Martins 1980,pp. 271-285. 


\subsection{Las obras relacionadas con el buen gobierno}

$\mathrm{Al}$ igual que en el campo más estrictamente literario, cobra importancia la dedicatoria del autor, que puede estar motivada muchas veces por una vinculación familiar, la relación directa o indirecta de las reinas e infantas con el contenido del texto o la propuesta de valores ejemplares.

Don Duarte ofrece el Leal conselheiro a su mujer, Leonor de Aragón, explicando en el prólogo que lo escribió a instancias suyas ${ }^{62}$. A primera vista, puede parecer sorprendente tal dedicatoria en un libro que la investigación histórica de las tres últimas décadas ha valorado por sus consideraciones sobre el buen gobierno, desarrolladas fundamentalmente a partir de los conceptos de prudencia y consejo. Desde luego, estos capítulos lo asemejan al género espejo de príncipes, destinado, por lo general, a los herederos al trono. Sin embargo, una lectura atenta del tratado y las mismas frases introductorias del rey ponen de manifiesto que su objetivo es la exposición de las reflexiones y vivencias personales de su autor: Muito prezada e amada Rainha Senhora: vós me requerestes que juntamente vos mandasse escrever algumas cousas que havía escritas por bom regimento de nossas consciências e vontades ${ }^{63}$. No obstante, el monarca es consciente del significado didáctico y ético-político de los citados pasajes y convierte en su receptor específico a los señores, miembros de sus Casas y jóvenes nobles ${ }^{64}$.

Los dos escritos dedicados a la futura Isabel de Castilla en 1468 tienen una clara finalidad política, que ha sido puesta de relieve por Ana Isabel Carrasco Manchado ${ }^{65}$. Tanto el Jardín de nobles doncellas, de fray Martín de Córdoba, como la Crianza y virtuosa doctrina, de Pedro Gracia Dei, se enmarcan en el golpe de estado ideológico contra Enrique IV y la legitimación consiguiente de la entonces aspirante al trono. Ambos autores titulan a Isabel, de forma ambivalente, señora natural de los reinos de Castilla, infanta de Castilla, señora infante, o utilizan expresiones sustitutivas de la realeza, como real señoría o persona real de reynos y reyes de grande riqueza.

Entre 1474 y 1496 se dirige la versión castellana del Memoriale virtutum a Isabel de Portugal, viuda de Juan II de Castilla, Los motivos alegados para ello son enteramente tópicos y se resumen en la alabanza a las virtudes de doña Isabel y el afán de proporcionarle una lectura provechosa para su tiempo de ocio $^{66}$. El prefacio suministra otra razón adicional: por su edad avanzada,

${ }^{62}$ Sobre Leonor de Aragón, véase Rodrigues 2012, 2014.

${ }^{63}$ Duarte 1982a, p. 21.

${ }^{64}$ Ibidem, pp. 23-24.

${ }^{65}$ Carrasco 2005, pp. 336-348; Nieto Soria 2006.

${ }^{66}$ Campos 2004, pp. 146-149. 
esta señora cumple una de las condiciones necesarias para la comprensión de aquesta sçiençia moral o de virtudes ${ }^{67}$. En un plano más general, este requisito puede contribuir a aclarar la preferencia habitual de las reinas sobre las infantas jóvenes como destinatarias de tratados.

Más allá de estas circunstancias, considero que el principal significado que encierra para la madre de Isabel I la adaptación de un original latino compuesto por Alonso de Cartagena para su tío don Duarte es que le pone en contacto con un elemento de su legado dinástico familiar. Esta hipótesis se ve corroborada por el probable origen portugués del anónimo traductor.

\subsection{La literatura del mundo clásico}

La única mención encontrada proviene de un préstamo realizado por María de Aragón a doña Aldonza de Mendoza, media-hermana del marqués de Santillana, que la duquesa de Arjona no devolvió, pues figura en la donación de diversos bienes otorgados por esta señora al monasterio de Lupiana, dentro de sus últimas voluntades: Iten otro libro escripto en pergamino que disen de treze dias enque esta tres treze dias con coberturas coloradas que disen ques dela reyna ${ }^{68}$. Teniendo en cuenta, las diferencias existentes entre la fonética castellana de la primera mitad del siglo XV y la actual, podría haberse producido una mala audición del copista al consignar un asiento que aludiría, en realidad a un manuscrito en pergamino de tragedias, que contiene tres tragedias. De ser así, como parece más probable, habría que pensar en las obras de Séneca. En este sentido, conviene recordar el fervor despertado en esos años por el filósofo cordobés en la corte de Castilla, sobre todo a partir de la traducción por Alonso de Cartagena de varios de sus tratados morales. Este conjunto circuló entre la nobleza a través de copias y también de préstamos, algunos de ellos realizados por el cónyuge de doña María, Juan II, a juzgar por dos entradas del inventario de la biblioteca del tercer conde de Benavente que hablan de un Séneca proveniente del monarca. El escribano Manuel Rodrígues de Sevilla lo utilizó para efectuar un traslado para su señor y escribió otro dos más, uno de ellos para entregar al caballero Gutierre de Quijada ${ }^{69}$. En este contexto, la alusión contenida en el inventario de los bienes donados

\footnotetext{
${ }^{67}$ Ibidem, p. 191.

${ }^{68}$ Inventario de este legado, realizado a instancias del convento, en Guadalajara, 30 de julio de 1435, AHN, Nobleza, Osuna, C. 1837, D. 4.

${ }^{69}$ [34] "Séneca en papel çebtí menor glosado que traslado Manuel Rodrigues de otro libro quel rey nuestro señor presto al señor conde con las tablas de papel cubiertas de cuero colorado (...) [38] Vn libro de Séneca en papel çebtí menor con tablas de papel cubiertas de cuero blanco el qual fue mandado por el señor conde que se diese a Gutierre Quixada. E escriuio
} 
a Lupiana por doña Aldonza parece indicar que la reina efectuaba una labor de difusión de manuscritos de este autor entre las damas, de manera similar a la de su esposo y los grandes magnates, pero los datos son demasiado escasos para poder pronunciarse sobre este punto.

De las tragedias de Séneca se hace eco el marqués de Santillana al definir este género literario en el prólogo a su Comedieta de Ponza, aún cuando diferencia equivocadamente el escritor literario del pensador moralista:

E tingendia [sic] es aquella que contiene en sy caydas de grandes reys e prínçipes, asy como de Ercoles, Panto [ $R$ Príamo] e Agamenón e otros tales, cuyos nasçimientos e vidas alegres se començaron, e grande tiempo se continuaron, e despues tristemente cayeron. E de fablar d'estos veo Séneca, el mançebo, sobrino del otro Séneca, en las sus Tragedias e Iohan Bocaçio en el libro De casibus virorum yllustrium ${ }^{70}$.

Al mismo tiempo, este pasaje, unida a la referencia al libro de Boccaccio, permite comprender las razones de la aceptación de estas obras: el tema de la rueda de la fortuna, la exhortación a practicar el estoicismo vital y a no vanagloriarse ni tomar una postura soberbia ante los éxitos, el tópico literario del ¿ubi sunt?, el gusto por las biografías y la fascinación por el ciclo troyano y, en general, por la materia de Roma. Por otra parte, la historia de Medea, incluida igualmente en el De claris mulieribus de Bocaccio puede considerarse un modelo femenino en negativo, que muestra, mejor que ningún otro, los comportamientos a evitar. En la biblioteca de la reina Isabel se hallaban también las tragedias de Séneca, aunque no estaban en pergamino, sino en papel: Otro libro escripto en papel, de mano, en rromançe, guarnesçido en cuero amarillo, que son las Trajedias de Séneca, de pliego pequeño. Dos manuscritos escurialenses, los S.II.7 y S.II.12 contienen el texto de las tragedias, pero en pliego entero ${ }^{71}$.

En cuanto a la traducción castellana, se atribuye a la iniciativa del marqués, a tenor de la carta a Pero González de Mendoza, fechable entre 1445 y 1452 . Nicolás G. Round la sitúa antes de $1436^{72}$. La relación de libros donados por su hermanastra corroboraría esta hipótesis, a no ser que existiera otra versión anterior y desconocida en la actualidad.

Manuel Rodrigues otro por el para el señor conde en papel çebtí menor”, Beceiro, Franco 2007, pp. 447-448, 464, 474-475.

${ }^{70}$ Santillana 1989, p. 238.

${ }^{71}$ Ruiz 2004, p. 500.

${ }^{72}$ Round 1974-1979, pp. 187-204. 


\subsection{Los tratados ejemplares para mujeres}

Se enmarcan en el debate sobre la condición femenina, que tiene lugar en la Europa Occidental desde mediados del siglo XIII. En los reinos de Castilla y Portugal, los tratados que arrojan una visión positiva fueron acogidos, traducidos o mandados imprimir por las reinas. La única salvedad está constituida por el Jardín de nobles doncellas que, en cierta manera, se asimila a esta situación, por su defensa de los derechos al trono de la infanta o princesa Isabel de Castilla. Su finalidad, en todos los casos, es proponer modelos de conducta a las damas de la corte y, en un sentido más amplio, al conjunto de las mujeres del reino.

Muy probablemente, se tradujo en el círculo de María de Aragón el De claris mulieribus de Bocaccio, pues en el citado donativo de la duquesa de Arjona a Lupiana se incluye otro libro pequeño escripto en papel çepti dela marca menor queparesçe quelo fiso Juan Vocaçio e fabla delas Dueñas con vnas coberturas cardenas $^{73}$. En cambio, resulta muy dudoso que don Álvaro de Luna compusiera a instancias suyas su Libro de las claras e virtuosas mugeres, dada la constante oposición de la soberana consorte al valido regio y, sobre todo, que la obra del condestable vio la luz en 1446, un año después del fallecimiento de doña María.

A esta señora ofrece Juan Rodríguez del Padrón el Triunfo de las donas y Diego de Valera el Tratado en defensa de virtuosas mujeres. Sus dedicatorias respectivas parecen responder, a primera vista, al afán habitual de los creadores de obtener el beneplácito del poder. Sin embargo, una mirada al contexto de la cultura cortesana en la Castilla de la primera mitad del siglo XV permite comprender por qué eligieron, en concreto, a esta destinataria.

Diana Pelaz sostiene que debe considerarse a doña María la autora causal de estos tratados, que delega en ambos autores para el proceso de escritura $^{74}$. La hipótesis es sugerente, pero muy discutible. La dedicatoria de un texto no implica necesariamente que su elaboración haya sido ordenada por el receptor y, además, en este caso no hay ninguna referencia en los dos prólogos que permita afirmarlo.

Más bien, puede explicar la opción por la reina el que los dos autores estimen que sus escritos tendrán un público femenino, por su misma temática, lo que afirma explícitamente Valera, quien, por otra parte, dirigió libros y opúsculos de temática muy diferente a representantes masculinos de la autoridad ${ }^{75}$.

${ }^{73}$ AHN, Nobleza, Osuna, C 1837, D. 4.

${ }^{74}$ Pelaz 2014.

${ }^{75}$ Santillana 1989, pp. 237-239. 
El encabezamiento del Triunfo de las donas, elaborado entre 1438 y 1445 , se adscribe enteramente a estos presupuestos. En él suma Rodríguez del Padrón la loa tópica a la belleza, virtudes e instrucción de la mujer de Juan II con el más específico reconocimiento a sus lazos de parentesco y afinidad: Princesa la muy mas digna et muy mas fermosa del universo, en grazia et virtudes singular, la muy enseñada et perfecta señora doña María por la divina inspiración, hermana de las tres reales coronas, e reina de la quarta, más soberana de los reinos de España ${ }^{76}$. Esta exaltación de la destinataria no supone el elevarla por encima de su marido, como sugiere Florence Serrano ${ }^{77}$, sino el recalcar su superioridad sobre las otras consortes peninsulares.

Hacia 1460, esta obra fue vertida al francés y presentada en un códice ricamente ornamentado a Felipe el Bueno de Borgoña, defensor del ideal cortés, que había situado a su ducado en centro de debate de la famosa Querelle des femmes. Le consagra el manuscrito Vasco Queimado de Villalobos, un caballero luso exiliado a la corte borgoñona tras la derrota en Alfarrobeira del infante-regente don Pedro, que, como ya se ha dicho, era hermano de la duquesa. Sin embargo, la introducción de uno de los ejemplares pone de manifiesto que el traductor fue Fernando de Lucena, un portugués que, junto con su más conocido hermano Vasco, había acompañado a Isabel de Portugal con ocasión de su matrimonio con el duque, el 7 de enero de 1430. De él se sabe que frecuentó la universidad de París y que participó en las embajadas de Carlos el Temerario a la península ibérica en 1473 y 1477, debido, muy probablemente a su conocimiento del castellano ${ }^{78}$.

Más extenso es el prólogo de Diego de Valera a su Tratado en defensa de virtuosas mujeres. Argumenta que, dado su contenido, es lógico dedicarlo a quien reúne la mayor dignidad y merecimientos entre todas las de su sexo y, al igual que otros autores y el mismo traductor del Memoriale virtutum, suplica a la soberana que enmiende lo que juzgue en falta y autorice lo que tenga por bien $^{79}$. También en esta ocasión pasó a poder de la reina Católica un ejemplar de esta obra, que tenía depositado en su cámara ${ }^{80}$.

El Jardín de nobles doncellas ya ha sido abordado en su vertiente política, que se inserta en el proceso de legitimación de la futura Isabel de Castilla. Pero las virtudes que fray Martín de Córdoba aconseja practicar a su destinataria, apenas se corresponden con la calidad regia que le otorga en varios pasajes.

\footnotetext{
${ }^{76}$ Rodríguez del Padrón 1982, p. 209.

${ }^{77}$ Serrano 2012, pp. 97-115.

${ }^{78}$ Pampín 1998, pp. 509-521.

${ }^{79}$ Valera 1959, p. 55. Para este autor, véanse los estudios recogidos por Montoya 2014.

80 "Un tratado de Diego de Valera, que fizo de loores a las mugeres, escripto en papel y es chequito", Ruiz 2004,p. 511.
} 
Como afirma Nieto Soria, el texto, en el que abundan las ejemplificaciones históricas y las referencias a la antigüedad, la tradición bíblica y las santas, acaba apuntando más a un modelo de soberana consorte que de reina propietaria ${ }^{81}$. Todo hace pensar que el fraile agustino, inmerso en la visión ideológica sobre la mujer imperante en la baja Edad Media, colocó en primer plano el cumplimiento ejemplar de las pautas marcadas para su sexo, que se requería a las grandes señoras, por encima de las actividades propias del gobierno.

A las reinas lusas Isabel y Leonor se debe el conocimiento y difusión de Christine de Pizan en su país, más concretamente de Le livre de trois vertus. La primera ordenó la versión a la lengua vernácula, presumiblemente en una época no muy posterior a su casamiento, en 1446. No se sabe cómo llegó el texto a la corte lisboeta. Quizás habría que pensar, de nuevo, en una conexión borgoñona, dada la mencionada aceptación en el ducado de los libros de este género, y el contacto de los anteriores titulares con la escritora, que ofreció a Juan sin Miedo un ejemplar de La cité des dames y a Margarita de Nevers otro de la obra tratada aquí.

En cualquier forma, la introducción al manuscrito conservado en la Biblioteca Nacional de Madrid nos informa, además de la iniciativa de la reina, de que la finalidad que buscaba la traducción era proporcionar un manual de comportamiento al entorno femenino de la soberana.

Aquy se come[n]ça o liu[r]o das tres vertudes e insinança das damas (...) o qual liu[r]o foy tornado de de ffrançes en esta nossa linguajem portugues por mandado da muyto exçellente e conprida de muytas vertudes senhora r[ainh] a dona Isabel molher do muyto alto e muyto exçelente e prinçipe e s[enho]r El rey don a[fons]o qynto de Portugal e do Algarue senhor de Çepta ${ }^{82}$.

La edición encargada por doña Leonor en 1518 presenta importantes variantes que no se limitan únicamente al cambio del título por el de $O$ espelho de Cristina. Resulta menos fiel al original francés y abrevia su parte última ${ }^{83}$. Sin embargo, participa del mismo espíritu que la versión mandada realizar por su antecesora, e incluso lo acentúa, ya que, aún cuando se cuando mantiene teóricamente la dimensión general del texto, va dirigida especialmente a un público principesco aristocrático y cortesano:

Aqui come[n]ça o liuro chamado espelho de Cristina o qual falla [sic] de tres estados de molheres $\mathrm{E}$ he partydo en tres partes A

${ }^{81}$ Nieto Soria 2006.

${ }^{82}$ BNM, Ms. 11.515.

${ }^{83}$ Sousa Rodrigues 2007, pp. 967-977. 
primeyra se endereça aas Raynhas. Prinçesas Duquesas e grandes senhoras A segu[n]da aas donzellas em espeçyal aquellas que anadam nas cortes das grandes prinçesas A terceyra aas molheres destado e burgesas [sic] de poboo comun.

El colofón del impresor Hermán Campos pone de manifiesto este objetivo y, en la línea de otros prólogos que destacan la intervención de la soberana a principios del siglo XVI, realza el prestigio de ella, mencionándola como cónyuge regia y no en su entonces situación de viuda:

Por mandado dela muyto esclareçida reyna dona Lyanor molher do poderoso y muy magnífico rey do[m] Juan segundo de Portugal. Acabose el libro intitulado das tres virtudes no qual se co[n] tem muytas probeytosas doutrinas y saludables enxemplos assy para as generosas y grandes donas como pera as outras de qual estado o condiçiom que sejam. E poderam en deprender como se ham de reger e gouernar no regimento de suas fazendas y honrras ${ }^{84}$.

\subsection{El teatro y la poesía cortesana}

Doña Leonor promueve o solicita la elaboración de la mayoría de los Autos de Gil Vicente entre 1502 y 1519. Su papel como principal mecenas literario durante esos años se explica, en principio, por ese status especial que tuvo durante los reinados de su hermano don Manuel I el Afortunado y su sobrino don João III, por encima de las consortes de estos monarcas y de la progenitora del primero de ellos, doña Beatriz. Se puede considerar como una figura tutelar de reina madre, forma superior de representación de la soberanía, que le es conferida como reconocimiento a su longevidad, su influencia decisiva en el acceso al trono de sus parientes directos, su dilatada presencia pública, su descendencia de la dinastía reinante y su calidad de memoria viva de su marido y las glorias de su reinado. Está concretada, básicamente, en la educación de los hijos menores, la gestión de sus bienes personales, la organización de redes de poder y el recurso a ella en actuaciones políticas, como la regencia, negociaciones diplomáticas y alianzas matrimoniales, funciones que ya había comenzado a desempeñar como princesa y esposa regia ${ }^{85}$.

El patrocinio del escritor tiene lugar a partir de la puesta en escena del Auto da Visitaçam, que exalta el nacimiento del futuro D. João III:

\footnotetext{
${ }^{84}$ Esta cita y la anterior están extraídas de $O$ espelho de Cristina, BNL 1987, ed. facsímil de la edición de Hermán Campos de 1515 [en línea en la web].

${ }^{85}$ Lourenço 2005, pp. 235-269.
} 
Entraram certas figuras de pastores e ofreceram ao Príncipe os ditos presentes. E por ser cosa nova em Portugal, gostou tanto a Rainha velha desta representação, que pediu ao autor que isto mesmo lhe representasse as matinas do Natal, enderesçadas ao nascimento do Redentor ${ }^{86}$.

A partir de entonces la intervención de la dama adopta dos modalidades básicas: la solicitud de nuevas obras y las diligencias para asegurar su difusión ante un público distinguido. A juzgar por las frases introductorias del Auto da Alma y el Auto dos quatro tempos, las actuaciones realizadas por primera vez en el palacio regio se presentan ante el rey don Manuel, por mandato de su hermana y luego tía del sucesor. Este mecanismo protocolario proporciona el espaldarazo para el mecenazgo directo de los monarcas y, al mismo tiempo, refleja la posición subsidiaria de la viuda de don João II ante la máxima autoridad del reino. En cambio, doña Leonor es la principal destinataria de las obras del autor que salen a la luz en sus escenarios específicos, las iglesias, monasterios y hospitales situados bajo su patronato y en los que ella ejercía de manera especial su beneficencia. La primera función pública del Auto de S. Martinho resulta especialmente significativa, pues tiene lugar en la iglesia de Santa María del Pópolo en Caldas, fundada por esta señora cuando era soberana consorte, dejando entonces su impronta en los emblemas heráldicos de la pareja regia que adornan la nave. La sibila Casandra es puesta en escena en el convento de Madre de Deus de Xábregas, objeto de varias donaciones suyas y, como ya se ha dicho, del legado de su biblioteca, y el Auto da barca do Purgatório es representado inicialmente en el Hospital de Todos los Santos de Lisboa, mandado erigir por el difunto marido de la dama. Puede adoptarse también una solución mixta: una primera representación ante la dama de A farsa chamada auto da fama y otra posterior, previsiblemente más solemne, para don Manuel.

A través de la lectura de estas obras queda patente que el interés de la reina viuda por ellas no sólo estaba motivado por los temas devotos y alegorías religiosas. Varios autos se adscriben al género de la égloga pastoril, y, al igual que en las composiciones de Juan del Encina, incluyen cantos populares y referencias a la vida cotidiana. En un contexto más amplio, aluden al motivo tópico del menosprecio de corte y alabanza de aldea, que cobró auge en la literatura peninsular durante la primera mitad del siglo XVI.

El bilingüismo del teatro de Gil Vicente responde al practicado por su público, que podía seguir con igual facilidad que las piezas escritas en su

\footnotetext{
${ }^{86}$ Buescu Carvalho 1985, vol. I, p. 22. Esta obra se ha tomado como base para las consideraciones sobre la relación entre la reina y el escritor, por lo que, en adelante, se omite toda referencia, salvo cita expresa.
} 
propia lengua las que empleaban exclusivamente el castellano o ponían este idioma en boca de determinados personajes, habitualmente pastores ${ }^{87}$. Se trata de una característica de la cultura portuguesa durante los siglos XV y XVI, tanto en su vertiente cortesana como erudita ${ }^{88}$.

Algunos de los escritos implicados en este patrocinio poseen una clara intencionalidad política. El monólogo del vaquero, contenido en el Auto da Visitaçãm, es un panegírico de las dos líneas de ascendencia del recién nacido príncipe, los Avís y los Trastamara castellanos, exaltando a sus progenitores, los antecesores en el trono, y las parientes más prestigiosas, entre las que se hallaba la futura benefactora del escritor ${ }^{89}$; el Auto da India se hace eco del impacto entre la sociedad portuguesa de la expansión ultramarina, y la Farsa chamada auto da fama reclama para Portugal la máxima consideración entre todas los países conocidos, nâo tâo somente pola gloria interesal dos comercios, mais principalmente polo infinito dano que os Mauros, amigos da nossa fé, recebem dos Portugueses na índica navegaçâ $o^{90}$. De nuevo se trae a colación el vínculo entre la gloria del reino luso, los descubrimientos, el consiguiente incremento territorial y la ampliación de la cristiandad, ya formulado en el proemio a la Vita Christi.

También fue presentada en la corte leonorina, al menos en una ocasión, la literatura poética compilada por García de Resende en su célebre Cancioneiro Geral. Tuvo lugar en Almada, en abril de 1500, ante un reducido grupo de doce personas. Once de ellas eran miembros de su Casa: Henrique da Mota, antiguo escribano de la reina, escudero suyo y juez de los huérfanos en Óbidos, maestre Gil, su médico, Agostinho Girão, caballero y arrendador mayor de la soberana, Afonso Fernandes Montarroio, su escudero y contador, João Álvares, escribano y secretario suyo, Diogo de Lemos, antiguo escribano y secretario y hombre de confianza de doña Leonor, Diogo Gonçalves, prior de San Pedro de Torres Vedras y su capellán mayor, Tomé Toscano, también capellán, que era además cantor, músico y organista de la capilla de esta señora, Bastião da Costa, que a sus funciones de capellán y cantor añadía la de escribano eclesiástico, Fernão Dias, escudero y encargado del guardarropa,

\footnotetext{
${ }^{87}$ Véase a este respecto Fernández 2004, pp. 83-100.

${ }^{88}$ Buescu 2004, pp. 13-38.

89 "Qué padre, que hijo y qué madre/ oh qué aguela y qué aguelos;/ Bendito Dios de los cielos,/ que le dió tal madre y padre ¡/ Qué tías, que yo me espanto", Buescu Carvalho 1985, vol. I, p. 22. La alusión a la abuela es oscura, pues puede referirse tanto a doña Beatriz, madre del rey don Manuel y doña Leonor, como, y más probablemente, a Isabel I de Castilla. La de las tías engloba a la últimamente citada y a la difunta infanta Isabel de Castilla, hija mayor de los Reyes Católicos, casada en primeras nupcias con el malogrado heredero al trono de Portugal don Alfonso, después con don Manuel, y hermana de doña María, madre del celebrado príncipe.

${ }^{90}$ Buescu Carvalho 1985, vol. II, p. 360.
} 
y Branca Álvares, la única presencia femenina, ocupada en la cristalería. A ellos se añade el mencionado dramaturgo ${ }^{91}$. Esta reunión pone de manifiesto la participación de los oficiales y criados de la Casa en las manifestaciones culturales de las dinastías reinantes.

Por otra parte, si se compara la protección dispensada a Gil Vicente con la que recibió su coetáneo Juan del Encina en Castilla, quedan patentes las diferencias en el poder regio entre ambos países del occidente peninsular. La centralización monárquica lusa y la debilidad de la nobleza conlleva un mecenazgo circunscrito a la familia regia, a su círculo de parentesco inmediato y a los monasterios vinculados a la Corona, como el de Odivelas, cuya abadesa encomienda en 1534 a Gil Vicente la realización del Auto da Cananea. En Castilla, en cambio, se crean cortes literarias y artísticas en torno a varios magnates, que recuerdan, aunque a mucha menor escala, las del ducado de Borgoña o las señorías y principados italianas. Esto permite al creador salmantino iniciar su carrera al servicio de los duques de Alba, a quienes dedicó varias de sus églogas, representadas, además, en el palacio de Alba de Tormes, para en una segunda etapa buscar el favor de los monarcas, dirigiendo tres composiciones alegóricas al príncipe don Juan y los Reyes Católicos, e, incluso, halló buena acogida por parte de los pontífices romanos y la curia cardenalicia.

\section{CONCLUSIONES}

El análisis de las iniciativas culturales de las reinas e infantas deja bien a las claras su importancia en el conjunto del occidente peninsular. No son empresas aisladas e inconexas, motivadas por las devociones privadas o por preferencias literarias individuales. Las desposadas fuera de su país de origen influyeron, en algunos casos, en el conocimiento de obras claves en la literatura didáctica y la espiritualidad e, indirectamente, intervinieron en la realización de traducciones, debidas a miembros de su entorno, que suponen un vínculo con su legado familiar y dinástico. Queda de manifiesto en algunas actuaciones de la duquesa de Borgoña. Cabe suponer que Filipa de Lancáster e Isabel de Portugal, madre de Isabel I de Castilla, influyeron en las traducciones de la Confessio amantis y del Memoriale virtutum, pero hay que insistir en que, hoy por hoy, no existe ningún dato que permita afirmar una intervención directa.

La labor de las soberanas consortes adopta varias modalidades: en principio, las dedicatorias denotan un papel simbólico, de reconocimiento de

${ }^{91}$ Sousa Carneiro 1993, pp. 51-52. 
autoridad y poder, al igual que ocurre con las ofrecidas a reyes, príncipes y señores masculinos. Pero los encargos de obras originales, copias y traducciones revelan un papel más activo y, en muchos casos, se inscribe en una línea de continuidad de las empresas culturales familiares, sobre todo entre los miembros femeninos de la dinastía Avís. Finalmente, el patrocinio de Leonor de Lancáster o Viseu con respecto a Gil Vicente constituye uno de los dos casos paradigmáticos de mecenazgo en el occidente peninsular, junto al dispensado por los duques de Alba a Juan del Encina.

Independientemente de las formas adoptadas, el mecenazgo de las soberanas consortes contribuye a la exaltación del poder regio, dentro de la imagen de la monarquía como educadora de sus súbitos en los principios y pautas de conducta que deben orientar su existencia y del círculo inmediato de servidores en materias específicas relacionadas con su función ${ }^{92}$. Complementa, en este sentido, la labor de sus esposos, que no puede ser entendida completamente por sí misma, sino dentro de esta totalidad.

\section{BIBLIOGRAFÍA CITADA}

Almeida, Manuel Lopes (ed.) (1977a), Chronica do senhor rey D. Affonso V, en Crónicas de Rui de Pina, Oporto, Lello \& Irmão, pp. 577-891.

Almeida, Manuel Lopes (ed.) (1977b), Chronica D'El señor rey D. João II, en Crónicas de Rui de Pina, Oporto, Lello \& Irmão, pp. 883-1033.

Alvar, Carlos; Lucía Megías, José Manuel (2003), Repertorio de traductores del siglo XV: tercera veintena, "Quaderns de Filología, Estudis Literaris" 8, pp. 1-40.

Álvarez Palenzuela, Vicente Ángel (2006), María, infanta de Aragón y reina de Castilla, en Marques, José (ed.), Estudos em homenagem ao professor doutor José Marques, Oporto, Universidad de Oporto, vol. IV, pp. 349-371.

Beceiro Pita, Isabel (1998), Cultura, ideología y mecanismos de gobierno en la dinastía lusa de los Avís, "Signo. Revista de Historia de la cultura escrita" 5, pp. 9-34.

Beceiro Pita, Isabel (2006), La recepción de la cultura aristocrática castellana en el Portugal de los Avís, Estudos em homenagem ao professor doutor José Marques, Oporto, Universidad de Oporto, vol. II, pp. 221-235.

\footnotetext{
${ }^{92}$ Para la imagen del rey como educador, y padre espiritual de sus súbditos, al final de la Edad Media, y en el caso portugués, véase Beceiro 2006; Rosa 2014.
} 
Beceiro Pita, Isabel (2007a), Modelos de conducta y programas educativos para la aristocracia femenina (siglos XII-XV), en Eadem (ed.), Libros, lectores y bibliotecas en la España medieval, Murcia, Nausicaã, pp. 287-321.

Beceiro Pita, Isabel (2007b), Los libros que pertenecieron a los condes de Benavente entre 1434 y 1530, en Eadem (ed.), Libros, lectores y bibliotecas en la España medieval, Murcia, Nausicaã, pp. 437-489.

Beceiro Pita, Isabel; Franco Silva, Alfonso (2007), Cultura nobiliar y bibliotecas. Cinco ejemplos, de las postrimerías del siglo XIV a mediados del XVI, en Eadem (ed.), Libros, lectores y bibliotecas en la España medieval, Murcia, Nausicaã, pp. 345-437.

Buescu, Ana Isabel (2001), A Confessio Amantis de John Gower na livraría do rei D. Duarte, en Sousa, Maria Leonor Machado de (ed.), Actas do I Congresso Internacional de Estudos Anglo-Portugueses, (Lisboa, 6-8 de maio de 2001), Lisboa, Faculdade de Cièncias Sociais e Humanas, pp. 67-75.

Buescu, Ana Isabel (2004), Aspectos do bilingüismo Portugués-castelhano na Época Moderna, "Hispania" 64/1, pp. 13-38.

Buescu, Ana Isabel (2007), Livros e livrarias de reis e de príncipes entre os séculos XV e XVI. Algumas notas, "eHumanista. Journal of Iberian Studies" 8, pp. 143-171.

Buescu, María Leonor Carvalho (ed.) (1985), Compilaçam de todas las obras de Gil Vicente, Lisboa, Imprensa Nacional-Casa da Moeda.

Campos Souto, Mar (2004), Memorial de virtudes de Alonso de Cartagena, Burgos, Ayuntamiento de Burgos.

Cano Ballesta, Juan (1989), Castigos y dotrinas que un sabio daua a sus hijas: un texto del siglo XV sobre educación femenina, en Vilanova, Antonio (dir.), Actas del X Congreso de la Asociación Internacional de Hispanistas (AIH), Barcelona, Promociones y Publicaciones Universitarias, pp. 139-150.

Carrasco Manchado, Ana Isabel (2005), La toma del poder de Isabel I de Castilla. Golpe a la legitimidad de Enrique IV, en Foronda, François; Genet, Jean-Philippe; Nieto Soria, José Manuel (dirs.), Coups d'État à la fin du Moyen Âge? Aux fondements du pouvoir politique en Europe occidentale, Madrid, Casa de Velázquez, pp. 336-348.

Cátedra, Pedro M. (1989), Alfonso Pérez de Madrigal y su Breviloquio de Amor y Amiciçia, en Idem, Amor y pedagogía en la Edad Media, Salamanca, Universidad de Salamanca, pp. 17-39.

Cortijo Ocaña,Antonio (1995), La traducción portuguesa de la Confessio Amantis de John Gower, "Evphrosyne" nova série 23, pp. 457-466. 
Cortijo Ocaña, Antonio (2000), La confessio amantis portugués en el debate del origen del sentimentalismo ibérico: un posible contexto de recepción, en Freixas, Margarita; Iriso Ariz, Silvia; Fernández, Laura (coords.), Actas del VIII congreso internacional de la asociación hispánica de literatura medieval, Santander, Gobierno de Cantabria - Año Jubilar Lebaniego - AHLM, pp. 583-586.

Cortijo Ocaña, Antonio (2007), El libro VI de la Confessio Amantis, "eHumanista. Journal of Iberian Studies" 8, pp. 37-72.

Cortijo Ocaña, Antonio; Oliveira, Maria do Carmo Correia (2007), $O$ Regimento dos Homees: el libro VII de la Confessio Amantis portuguesa, "Revista de Literatura Medieval" 19, pp. 7-124.

Coelho, Maria Helena da Cruz (2005), O senhor do pelícano da lei e da grei, en Mendoça, Manuela (ed.), O tempo histórico de D. João II nos 550 anos do seu nascimento, Actas do colóquio 2, 3 e 4 de Maio de 2005, Lisboa, Academia Portuguesa da História, pp. 174-175.

Chartier, Roger (1996), Poder y escritura: el príncipe, la biblioteca y la dedicatoria (siglos XV-XVII), "Manuscrits" 14, pp. 202-203.

Duarte (1982a), Leal conselheiro, ed. de João Morais Barbosa, Lisboa, Imprensa Nacional-Casa da Moeda.

Duarte (1982b), Livro dos conselhos de El-Rei D. Duarte (livro da cartuxa), Lisboa, Imprensa universitaria - editorial Estampa.

Echevarría Arsuaga, Ana (2005), The Queen and the Master: Catalina of Lancaster and the Military Orders, en Earenfight, Theresa (ed.), Queenship and Political Power in Medieval and Medieval and Early Modern Spain, Aldershot, Ahsgate, pp. 91-105.

Echevarría Arsuaga, Ana (2012), Dinastía. Reinas mecenas en los albores del Renacimiento, en Serrano de Haro Soriano, Amparo; Alegre Carvajal, Esther (coords.), Retrato de la mujer renacentista, Madrid, UNED, pp. 67-89.

Fernández García, María Jesús (2004), Personajes que hablan castellano en el teatro portugués del siglo XVI: (II) El pastor, "Anuario de Estudios Filológicos" 27, pp. 83-100.

Flórez, Enrique (1761), Memorias de las reinas católicas. Historia genealógica de la Casa Real de Castilla y León, Valladolid, Junta de Castilla y León [reimpresión 2002].

García y García, Antonio (1976), La canonística ibérica medieval posterior al Decreto de Graciano (III), en Repertorio de historia de las ciencias eclesiásticas en España, vol. V, siglos III-XVI, Salamanca, Instituto de la Teología Española - Universidad Pontificia de Salamanca, pp. 397-454. 
Gómez Redondo, Fernando (2007), Historia de la prosa medieval castellana, vol. III. Los orígenes del humanismo: el marco cultural de Enrique III y Juan II, Madrid, Cátedra.

Jardin, Jean-Pierre (2006), Le rôle politique des femmes dans la dynastie Trastamare, "e-Spania" [en línea] 1, DOI: 10.4000/e-spania.322.

Lourenço, María Paula (2005), D. Leonor de Lencastre (1471-1525): imagem e poderes da rainha-mãe, en $O$ tempo histórico de D. João II. nos 550 anos do seu nascimento. Actas do colóquio 2, 3 e 4 de Maio de 2005, Lisboa, Academia Portuguesa da História, pp. 235-269.

Martins, Mario (1958), A rainha dona Leonor e os libros, "Brotéria" 67/4, pp. 249-257.

Martins, Mario (1961), O breviario franciscano da Rainha D. Leonor, "Brotéria" 72, pp. 510-522.

Martins, Mario (1965), Bernardo de Brihuega, compilador dos "Autos dos Apóstolos", "Boletim de Filología" 21, pp. 69-86,

Martins, Mario (1980), Bosco deleitoso, en Idem, Alegorías, símbolos e exemplos morais da literatura medieval portuguesa, Lisboa, Brotéria, pp. 271-285.

Montoya García, Cristina (ed.) (2014), Mosén Diego de Valera. Entre las armas y las letras, Woodbridge, Támesis.

Monumenta Henricina (1974), Coimbra, Comissão executiva das comemorações do V centenário da morte do infante D. Henrique, vol. XV, suplemento 188.

Nascimento, Aires A. (2001), A Vita Christi de Ludolfo de Saxónia em portugués: percursos da tradução e seu presumivel responsável, "Euphrosyne" 29, pp. 125-142.

Nieto Soria, José Manuel (2006), Ser reina, "e-Spania" [en línea] 1, DOI: 10.4000/e-spania.322.

Pampín Barral, Mercedes (1998), Una traducción al francés del Triunfo de las donas de Juan Rodríguez del Padrón, en Parrilla, Carmen (ed.), Actas del I Congreso de Jóvenes Filólogos. Edición y anotación de textos, A Coruña, Universidade da Coruña, vol. II, pp. 509-521.

Parrilla, Carmen (ed.) (1998), Las çinco figuratas paradoxas, Alfonso Fernández de Madrigal, El Tostado, Alcalá de Henares, Universidad de Alcalá de Henares.

Parrilla, Carmen (2004), En torno a las versiones de las çinco figuratas paradoxas: diversidades y hermosuras de un traslado, "La Corónica" 33/1, pp. 125-143.

Parrilla, Carmen (2004-2005). Qui scit, docere habet. Acerca de Alfonso de Madrigal el Tostado, "Archivum: Revista de la Facultad de Filología” 54-55, pp. 367-390. 
Pelaz Flores. Diana (2013), La imagen de la reina consorte como muestra de poder en el reino de Castilla durante el siglo XV. Construcción y significado, "Medievalismo" 23, pp. 265-291.

Pelaz Flores, Diana (2014), A la más virtuossa de las mujeres. La reina María de Aragón (1420-1445) como impulsora de las letras en la Corona de Castilla, "Hispania" 74/247, pp. 331-356.

Reinhardt, Klaus; Santiago Otero, Horacio (1986), Biblioteca bíblica ibérica medieval, Madrid, CSIC.

Ruiz García, Elisa (2004), Los libros de Isabel la Católica. Arqueología de un patrimonio escrito, Salamanca, Instituto de Historia del Libro y la Lectura.

Rodrigues, Ana Maria, S. A. (2007), The Queen Consort in Late Medieval Portugal, en Bolton, Brenda; Meek, Christine (ed.), Aspects of Power and Authority in the Middle Ages, Turnhout, Brepols, pp. 131-145.

Rodrigues, Ana Maria, S. A. (2012), As tristes rainhas. Leonor de Aragậo. Isabel de Coimbra, Lisboa, Círculo de Leitores.

Rodrigues, Ana Maria, S. A. (2014), Polla Raynha dona lionor mjnha moler que sobre todas amo e preço. D. Duarte e D. Leonor, uma parcería aquém e além túmulo, en Fernandes Barreira, Catarina; Seixas, Miguel Metelo (coords.), D. Duarte e a sua época. Arte, cultura, poder e espiritualidade, Lisboa, IEM - CLEGH, pp. 67-83.

Rodríguez del Padrón, Juan (1982), Obras completas, ed. C. Hernández Alonso, Madrid, Castalia.

Rosa, Maria de Lurdes (2014), D. Duarte e os almas das defuntos. Bens espirituais, caridade e misericórdia na reconfiguraçảo do poder régio, en Fernandes Barreira, Catarina; Seixas, Miguel Metelo de (coords.), D. Duarte e a sua época. Arte, cultura, poder e espiritualidade, Lisboa, IEM - CLEGH, pp. 127-153.

Round, Nicholas G. (1974-1979), Las traducciones medievales, catalanas y castellanas, de las Tragedias de Séneca, "Anuario de Estudios Medievales" 9, pp. 187- 204.

Sá, Isabel dos Guimarậes (2011), Da Princesa a Rainha Velha. Leonor de Lancaster, Lisboa, Círculo de Leitores.

Salvador Miguel, Nicasio (2004a), El mecenazgo literario de Isabel la Católica, en Isabel la Católica. La magnificencia de un reinado, Madrid, Sociedad estatal de conmemoraciones culturales - Junta de Castilla y León, pp. 75-86.

Salvador Miguel, Nicasio (2004b), La actividad literaria en la corte de Isabel la Católica, en Isabel la Católica. Los libros de la reina, Burgos, Instituto Castellano y Leonés de la Lengua, pp. 171-96. 
Salvador Miguel, Nicasio (2009), Isabel la Católica. Educación, mecenazgo y entorno literario, Alcalá de Henares, Centro de Estudios Cervantinos.

Santano Moreno, Bernardo (1998), La traducción del Confessio Amantis de John Gower, "Anuario de Estudios Filológicos" 12, pp. 253-285.

Santillana, marqués de (1989), La comedieta de Ponza, en Poesías completas, t. I, ed. Manuel Durán, Madrid, Castalia.

Serrano, Florence (2012), Del debate a la propaganda política mediante la Querella de las mujeres en Juan Rodríguez del Padrón, Diego de Valera y Álvaro de Luna, "Talia Dixit" 7, pp. 97-115.

Serrão, Joaquín Veríssimo (ed.) (1973), García de Resende, Crónica de D. João II e Miscelânea, Lisboa, Imprensa Nacional-Casa da Moeda.

Silleras Fernández, Nuria (2005-2006), Reginalitat a l'Edat Mitjana hispànica: concepte historiogràfic per a una realitat històrica, "Butlletí de l'Acadèmia de Bones Lletres de Barcelona" 50, pp. 121-142.

Silva, Manuela Santos (2012a), A literacia de Filipa de Lencastre, "Férula" 1, pp. 29-33.

Silva, Manuela Santos (2012b), A rainha inglesa de Portugal. Filipa de Lencastre, Lisboa, Circulo de leitores.

Sousa Carneiro de, Ivo (1993), Introduçâo ao Estudo do patrimônio, da casa $e$ da corte de D. Leonor, en Espiridualidade e Corte em Portugal (Séculos XVI a XVIII). Porto, 28 a 30 de maio de 1992, Oporto, Institudo de Cultura Portuguesa, 1993, pp. 23-52 (Anexo V de Revista de Facultade de Letras; Série Línguas e Literaturas).

Sousa, Sara Rodrígues de (2007), Christine de Pizan em portugués, Actas del XI congreso internacional de la Asociación Hispánica de Literatura Medieval, (León. 20-24 de septiembre de 2005), León, Universidad de León, vol. II, pp. 967-977.

Tejada, Francisco Elías de (1998), La tradición portuguesa. Los orígenes (1140-1521), Madrid, Fundación Francisco Elías de Tejada.

Valera, Diego de (1959), Tratado en defensa de virtuossas mujeres, en Penna, Mario (ed.), Prosistas castellanos del siglo XV, ed. y estudio preliminar de Mario Penna, Madrid, Atlas (Biblioteca de Autores Españoles; 96).

Villares, Isabel Cepeda (1987), Os libros da rainha D. Leonor segundo o códice 11352 da Biblioteca Nacional, Lisboa, "Revista da Biblioteca Nacional" Serie 2, 2/2, pp. 51-81.

Viterbo, Francisco de Sousa (1901), A livraria real especialmente no reinado de D. Manuel, Lisboa, Typographia da Academia.

Fecha de recepción del artículo: mayo 2015

Fecha de aceptación y versión final: febrero 2016 